K. Staiger - H. Staiger - M. A. Schweitzer •

E. Metzinger · B. Balletshofer · H.-U. Häring •

M. Kellerer

\title{
Insulin and its analogue glargine do not affect viability and proliferation of human coronary artery endothelial and smooth muscle cells
}

Received: 28 October 2004 / Accepted: 4 April 2005 / Published online: 3 August 2005

(C) Springer-Verlag 2005

\begin{abstract}
Aims/hypothesis: Present guidelines for the treatment of type 2 diabetes recommend $\mathrm{HbA}_{1} \mathrm{c}$ values of less than $7 \%$. As beta cell function worsens during progress of the disease, insulin therapy is often necessary to achieve this ambitious goal. However, due to peripheral insulin resistance, many patients need rather high insulin dosages. In the light of the extremely high cardiovascular risk of diabetic patients, it is important to determine whether high concentrations of insulin or its frequently used analogues are harmful to the cardiovascular system. We therefore investigated the modulatory effects of regular human insulin and its analogue glargine on proliferation and apoptosis of human coronary artery endothelial cells (HCAECs) and human coronary artery smooth muscle cells (HCASMCs). Methods: Cells were treated with regular human insulin or insulin glargine. Proliferation was determined by $\left[{ }^{3} \mathrm{H}\right]$ thymidine incorporation and by flow cytometric analysis of Ki-67 expression. Apoptosis was assessed by flow cytometry (cell cycle analysis and annexin V staining) and determination of caspase-3 activity. Results: HCAECs and HCASMCs treated with regular human insulin or insulin glargine did not show significant increases in DNA synthesis or Ki-67 expression. Administration of regular human insulin or insulin glargine did not modulate the extent of apoptotic events. No influence of insulin on lipoapoptotic vascular cell death could be detected.
\end{abstract}

K. Staiger - H. Staiger $\cdot$ E. Metzinger $\cdot$ B. Balletshofer $\cdot$

H.-U. Häring $\cdot$ M. Kellerer $(\bowtie)$

Internal Medicine IV, University of Tübingen,

Otfried-Muller-Str. 10,

72076 Tübingen, Germany

e-mail: MonikaKellerer@vinzenz.de

Tel.: +49-711-64892102

Fax: +49-711-64892119

M. A. Schweitzer

Aventis Pharma Germany,

Bad Soden am Taunus, Germany

M. Kellerer

Internal Medicine I, Marienhospital,

Böheimstr. 37,

70199 Stuttgart, Germany
Conclusions/interpretation: Taken together, neither regular human insulin nor insulin glargine influences growth and apoptosis of human coronary artery cells in vitro. Our data do not suggest that regular human insulin or insulin glargine promote atherosclerosis through mechanisms affecting the cellularity of human coronary arteries.

Keywords Apoptosis - Atherosclerosis - Diabetes · Glargine - Human coronary artery endothelial cells . Human coronary artery smooth muscle cells · Insulin . Insulin resistance $\cdot$ Proliferation

Abbreviations EGM: endothelial cell growth medium HCAEC: human coronary artery endothelial cell .

HCASMC: human coronary artery smooth muscle cell . SMGM: smooth muscle cell growth medium

\section{Introduction}

Current guidelines define $\mathrm{HbA}_{1} \mathrm{c}$ values of less than 7.0\% as the therapeutic goal for type 2 diabetic patients. Due to the natural course of type 2 diabetes with its progressive loss of beta cell function, it often becomes necessary to add insulin to oral therapy to achieve better glycaemic control [1-3]. Recently, Riddle et al. [4] demonstrated that even a simple insulin regimen lowers $\mathrm{HbA}_{1} \mathrm{c}$ levels to $6.9 \%$ in type 2 diabetic patients. However, due to peripheral insulin resistance, most of the patients needed rather high insulin dosages $[4,5]$. In this and other trials, the insulin analogue glargine was shown to improve glycaemic control with significantly less nocturnal hypoglycaemia than NPH insulin $[2-4,6]$. Therefore, insulin and its analogue glargine are increasingly being used in type 2 diabetic patients to reach the desired $\mathrm{HbA}_{1} \mathrm{c}$ levels.

As type 2 diabetic patients as a group have extremely high cardiovascular morbidity and mortality, and specifically in the light of the increasing use of insulin glargine with its increased affinity for IGF-I receptors [7], the question of whether high concentrations of insulin may be harmful for the vascular system is again a matter of con- 
cern. The role of hyperinsulinaemia as an independent risk factor for cardiovascular disease has been debated for years. An association between increased plasma insulin and the risk of cardiovascular disease has been found in many, but not all, prospective studies (for meta-analysis see [8]). Notably, most of these studies were performed in nondiabetic patients. Currently, evidence is accumulating that insulin therapy in diabetic patients has rather beneficial effects on the cardiovascular system. It has been shown to normalise lipid abnormalities by reducing total plasma triglycerides and increasing plasma HDL-cholesterol, and also to improve endothelial function, determined by measuring forearm blood flow responses to endothelium-dependent vasodilators $[5,6,9,10]$. Furthermore, insulin exerts anti-inflammatory effects, i.e. insulin therapy reduces levels of pro-inflammatory cytokines and C-reactive protein in critically ill patients [11-13].

The mechanisms of insulin's actions on vascular cells are still under debate. Human arterial smooth muscle cells express both insulin and IGF-I receptors [14, 15]. Mitogenic effects of insulin in vitro, however, were only detected when insulin was present in sufficient concentrations to interact with the IGF-I receptor [16]. Analogous results were obtained in rat and porcine vascular smooth muscle cells, where low concentrations of insulin showed only little or no mitogenic activity in vitro, while higher concentrations of insulin promoted cell growth in some studies, depending on the vessel type [17-20].

Vascular endothelial cells express insulin receptors as well as IGF-I receptors [21-23]. HUVECs contain approximately 3.5-10 times more IGF-I receptor mRNA than insulin receptor mRNA [24, 25]. This is reflected by significantly more IGF-I receptors than insulin receptors (approximately $400,000 /$ cell and 40,000/cell, respectively) [25]. Furthermore, insulin was shown to prevent HUVECs from apoptosis induced by TNF- $\alpha$ or angiotensin II [26].

The growing necessity to use high doses of insulin or insulin analogues in the therapy of type 2 diabetes provides the rationale to extensively study the effects of insulin and its analogues on the cardiovascular system. Therefore, we studied the effects of regular human insulin and the insulin analogue glargine on proliferation and apoptosis of human coronary artery endothelial cells (HCAECs) and human coronary artery smooth muscle cells (HCASMCs).

\section{Materials and methods}

\section{Cell culture}

HCAECs and HCASMCs were purchased from Clonetics/ BioWhittaker and cultured in endothelial cell growth medium (EGM) or smooth muscle cell growth medium (SMGM) with supplements according to the provider's instructions. Cells were obtained from healthy donors (1656 years old), who had given their informed consent. Cells were treated with regular human insulin or insulin glargine (Aventis Pharma, Bad Soden, Germany). In some experiments, cells were incubated with NEFA. NEFA (Sigma-
Aldrich, Taufkirchen, Germany) were bound to fatty-acidfree BSA as previously described [27].

Determination of $\left[{ }^{3} \mathrm{H}\right]$ thymidine incorporation

Cells were seeded in six-well plates $(20,000$ cells/well). After attachment overnight, cells were starved for $16 \mathrm{~h}$ in unsupplemented EGM/SMGM medium containing 0.5\% FCS. Then, cells were treated for $20 \mathrm{~h}$ as indicated. $\left[{ }^{3} \mathrm{H}\right]$ Thymidine $(55.5 \mathrm{kBq} / \mathrm{ml})$ was added for the final $4 \mathrm{~h}$. The dishes were rinsed twice with ice-cold PBS before 10\% trichloroacetic acid was added for $20 \mathrm{~min}$. After dishes were washed once with ice-cold $10 \%$ trichloroacetic acid, cells were lysed with $500 \mu \mathrm{l} 0.2 \mathrm{~mol} / 1 \mathrm{NaOH} / 1 \%$ SDS, and the lysates were neutralised with $0.2 \mathrm{~mol} / 1 \mathrm{HCl}$. The incorporated radioactivity was determined by liquid scintillation counting.

\section{Flow cytometric analysis of Ki-67 expression}

Cells were grown to $50 \%$ confluence in $10 \mathrm{~cm}$ dishes and starved for $16 \mathrm{~h}$ in unsupplemented EGM/SMGM medium containing $0.5 \%$ FCS. Cells were treated for $20 \mathrm{~h}$ as indicated, harvested by trypsinisation, washed once with wash buffer (PBS/0.1\% NaN $/ 1 \%$ heat-inactivated $\mathrm{FCS}$ ) and fixed in $70 \%$ ice-cold ethanol. After at least $24 \mathrm{~h}$ incubation at $-20^{\circ} \mathrm{C}$, cells were washed with wash buffer, resuspended in wash buffer containing $0.25 \%$ Triton X-100, and incubated on ice for $5 \mathrm{~min}$. Permeabilised cells were washed again and resuspended in wash buffer containing FITC-conjugated anti-Ki-67 antibody (BD Biosciences Pharmingen, San Diego, CA, USA). Cells were incubated for $30 \mathrm{~min}$ at room temperature, washed again and then subjected to flow cytometry using a Becton Dickinson FACScalibur cytometer (BD Biosciences Immunocytometry Systems, San Jose, CA, USA). Percentages of Ki67-positive cells were calculated by CellQuest software (Becton Dickinson).

\section{Immunoblotting}

Cells were serum-starved overnight. After stimulation as indicated, cells were lysed in ice-cold lysis buffer (50 mmol/1 HEPES pH7.2, $150 \mathrm{mmol} / 1 \mathrm{NaCl}, 1.5 \mathrm{mmol} / \mathrm{l}$ $\mathrm{MgCl}_{2}, 1 \mathrm{mmol} / 1$ EGTA, $10 \%$ (v/v) glycerol, $1 \%(\mathrm{v} / \mathrm{v})$ Triton $\mathrm{X}-100,100 \mathrm{mmol} / \mathrm{l} \mathrm{NaF}, 10 \mathrm{mmol} / \mathrm{l}$ sodium pyrophosphate, $100 \mu \mathrm{mol} / 1$ sodium orthovanadate, $1 \mathrm{mmol} / 1$ phenylmethylsulphonylfluoride, $10 \mu \mathrm{g} / \mathrm{ml}$ aprotinin). Cleared crude cell lysates $(20 \mathrm{~min}$ at $12,000 \mathrm{~g}$ ) were analysed on a $10 \%$ SDS polyacrylamide gel (100 $\mu \mathrm{g}$ protein per lane). Separated proteins were transferred to nitrocellulose membranes by semi-dry electroblotting (transfer buffer: $48 \mathrm{mmol} / 1 \mathrm{Tris}-\mathrm{HCl} \mathrm{pH} 7.5,0.0004 \%$ (w/v) SDS, $39 \mathrm{mmol} / \mathrm{l}$ glycine, $20 \%(\mathrm{v} / \mathrm{v})$ methanol). Equal loading was confirmed by Ponceau S staining. After transfer, the membranes were blocked with NET buffer $(150 \mathrm{mmol} / \mathrm{l}$ 
Fig. 1 No effect of regular human insulin or insulin glargine on $\left[{ }^{3} \mathrm{H}\right]$ thymidine incorporation. a HCAECs or HCASMCs were serum-starved for $16 \mathrm{~h}$ in unsupplemented basal medium containing $0.5 \%$ FCS. Cells were then stimulated with growth medium containing $10 \%$ FCS (as a positive control), basal medium or basal medium containing $10 \mathrm{nmol} / 1$ regular insulin or insulin glargine. $\left[{ }^{3} \mathrm{H}\right]$ Thymidine incorporation was determined as described in Materials and methods. b HCASMCs were incubated with the indicated concentrations of regular insulin or insulin glargine and $\left[{ }^{3} \mathrm{H}\right]$ thymidine incorporation was determined as described. Data are means \pm SE of six independent experiments in triplicate. Open bars, basal medium; hatched bars, growth medium; black bars, regular insulin; grey bars, insulin glargine $\mathbf{a}$

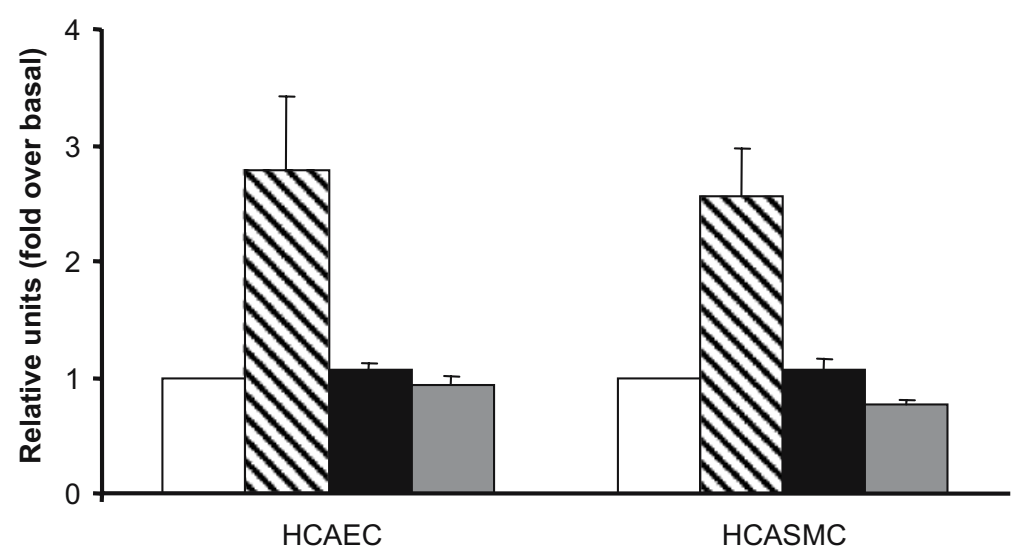

b

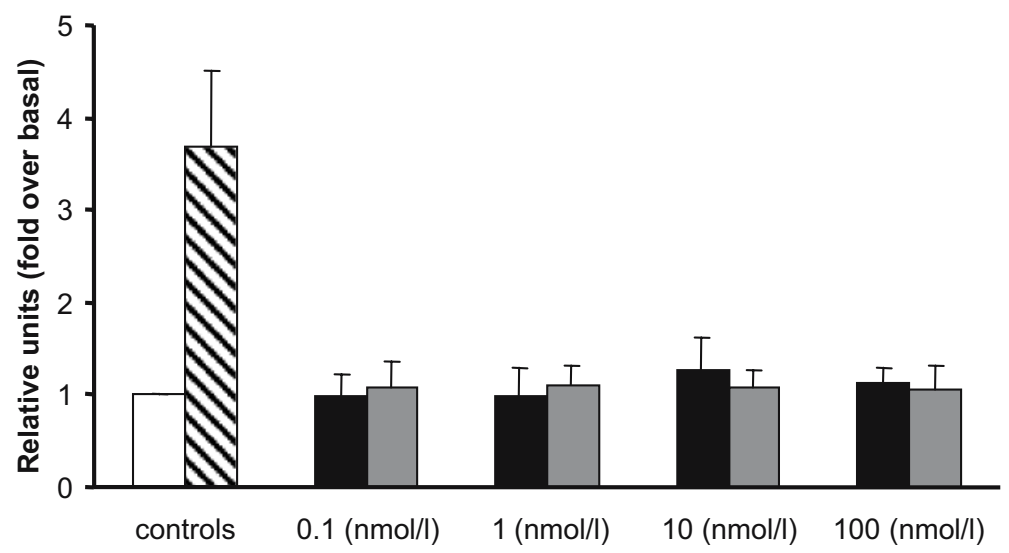

$\mathrm{NaCl}, 5 \mathrm{mmol} / 1$ EDTA, $50 \mathrm{mmol} / 1$ Tris, 0.05\% (v/v) Triton $\mathrm{X}-100$ and $0.25 \%(\mathrm{w} / \mathrm{v})$ gelatine, $\mathrm{pH} 7.4)$ for $1 \mathrm{~h}$. Subsequently, filters were incubated with the primary antibody (anti-Phospho-Akt; Cell Signaling, New England Biolabs, Frankfurt/Main, Germany) overnight at $4^{\circ} \mathrm{C}$. The membranes were washed four times with NET buffer before incubating with horseradish-peroxidase-conjugated antirabbit $\operatorname{IgG}$ for $1 \mathrm{~h}$ at room temperature. Immunocomplexes were visualised by enhanced chemiluminescence.

\section{Cell cycle analysis}

Confluent cells were treated as indicated. Detached cells were harvested from the supernatant by centrifugation and added to the adherent cells harvested by trypsinisation. Cells were washed with PBS, fixed in 70\% ice-cold ethanol, centrifuged and washed again with PBS. After staining with propidium iodide $(50 \mu \mathrm{g} / \mathrm{ml})$ diluted in PBS containing RNase A $(100 \mu \mathrm{g} / \mathrm{ml})$, cells were subjected to flow cytometric analysis of DNA content using the FACScalibur cytometer. Percentages of cells in the different cell cycle phases were calculated by CellQuest software.
Propidium iodide-annexin V double staining

Cells were harvested and washed as described above (cell cycle analysis). Cells were double stained with propidium iodide $(1 \mu \mathrm{g} / \mathrm{ml})$ and annexin V-Fluos (Roche Diagnostics) according to the manufacturer's instructions. Stained cells were subjected to flow cytometry (FACScalibur cytometer). Percentages of necrotic, apoptotic and vital cells were calculated by CellQuest software.

Table $1 \mathrm{Ki}-67$ expression (per cent Ki-67-positive cells) in HCAECs and HCASMCs

\begin{tabular}{lrr}
\hline & HCAECs & HCASMCs \\
\hline Growth medium & $56.01 \pm 1.91$ & $32.37 \pm 5.19$ \\
Basal medium & $9.11 \pm 0.68$ & $2.45 \pm 0.32$ \\
$+10 \mathrm{nmol} / 1$ regular insulin & $8.39 \pm 0.65$ & $2.51 \pm 0.48$ \\
$+10 \mathrm{nmol} / 1$ insulin glargine & $8.89 \pm 1.01$ & $2.44 \pm 0.35$ \\
\hline
\end{tabular}

Data are means \pm SE $(n=4)$ 
Fig. 2 Regular human insulin and insulin glargine phosphorylate protein kinase $\mathrm{B}$.

HCAECs and HCASMCs were stimulated as indicated. Immunoblotting was performed as described in Materials and methods

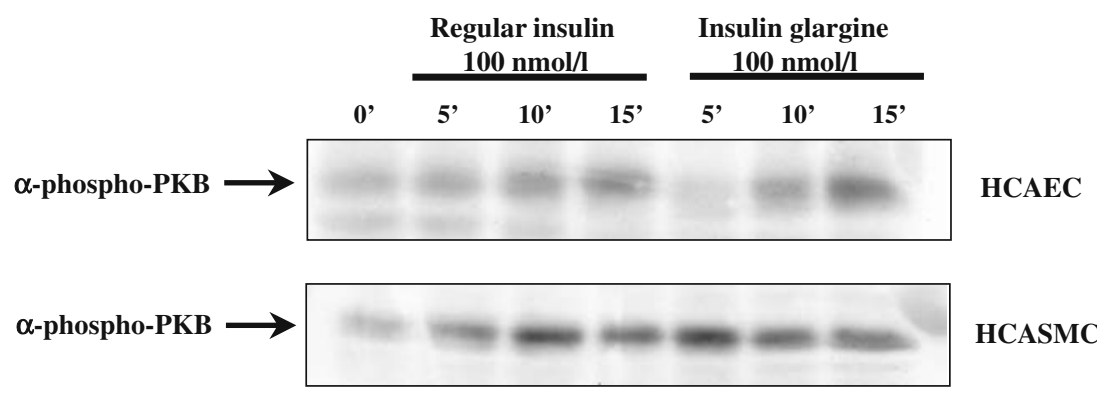

Measurement of DEVD-amc-cleaving caspase activity

Cells were seeded in triplicates in 96-well plates at a density of $10^{4}$ cells/well. After stimulation as indicated, the cells were incubated in lysis buffer $(25 \mathrm{mmol} / 1 \mathrm{Tris}-\mathrm{HCl}$ $\mathrm{pH}$ 8.0, $60 \mathrm{mmol} / \mathrm{l} \mathrm{NaCl}, 2.5 \mathrm{mmol} / \mathrm{l}$ EDTA, $0.25 \% \mathrm{NP} 40$ ) for $10 \mathrm{~min}$. Then, the fluorogenic caspase-3 substrate AcDEVD-amc (12 $\mu \mathrm{mol}$; BACHEM, Weil am Rhein, Germany) was added and the fluorescence determined at $15 \mathrm{~min}$ intervals using $360 \mathrm{~nm}$ excitation and $480 \mathrm{~nm}$ emission wavelengths (Mithras Multilabel reader LB940; Berthold Technologies, Bad Wildbad, Germany).
Statistics

Data were analysed by one-way ANOVA with Bonferroni's post-hoc test. A $p$ value less than 0.05 was considered statistically significant. For these tests, the statistical software SigmaStat for Windows 1.0 (Jandel, San Rafael, CA, USA) was used.

\section{Results}

To study the influence of regular human insulin and insulin glargine on proliferation of human coronary artery cells,
Fig. 3 Viability of a HCAECs or b HCASMCs is not altered by regular insulin or insulin glargine. a HCAECs were cultured for $24 \mathrm{~h}$ in growth medium in the absence or presence of regular insulin or insulin glargine at different concentrations. Apoptosis was determined as described in Materials and methods. Data are means \pm SE of three independent experiments $(n=3)$. Hatched bar, growth medium; black bar, regular insulin; grey bar, insulin glargine. b HCASMCs were incubated with regular insulin or insulin glargine for $24 \mathrm{~h}$ at the indicated concentrations and percentages of necrotic and apoptotic cells were determined by propidium iodide-annexin V double staining. Data are means \pm SE of four independent experiments. Solid shading, apoptosis; no shading, necrosis; grey shading, late apoptosis/necrosis

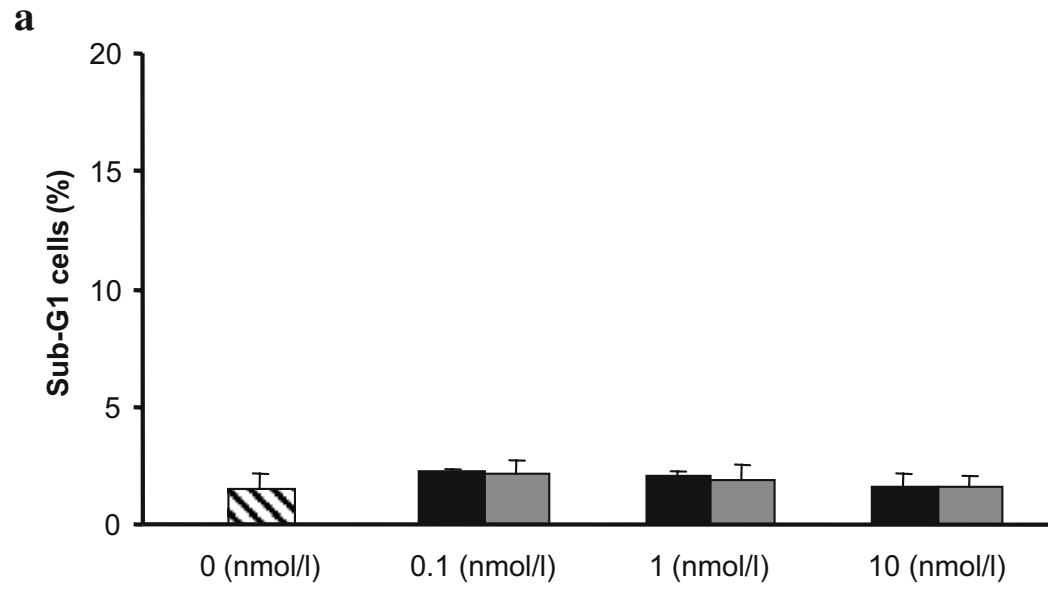

b

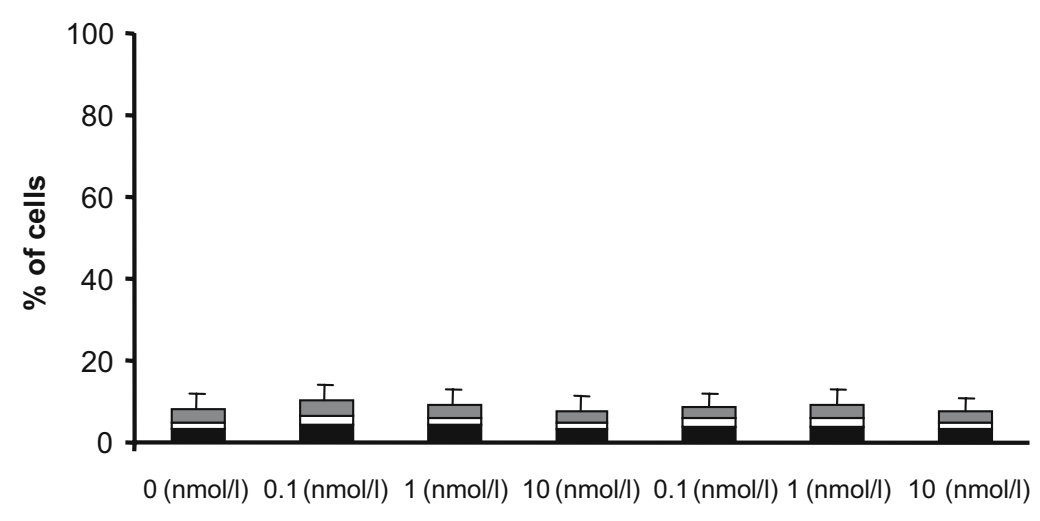


DNA synthesis was determined by $\left[{ }^{3} \mathrm{H}\right]$ thymidine incorporation. All cells were serum-starved overnight prior to stimulation. As a positive control, serum-starved cells were incubated with growth medium containing $10 \%$ FCS. Under this condition, the $\left[{ }^{3} \mathrm{H}\right]$ thymidine incorporation rate increased approximately 2.5 -fold over basal (unsupplemented basal medium containing $0.5 \%$ FCS) in both cell types (Fig. 1a). By contrast, regular human insulin and insulin glargine, at $10 \mathrm{nmol} / 1 \mathrm{each}$, did not significantly increase $\left[{ }^{3} \mathrm{H}\right]$ thymidine incorporation. Since HCASMCs showed a tendency towards lower $\left[{ }^{3} \mathrm{H}\right]$ thymidine incorporation after treatment with insulin glargine, we tested a potential anti-proliferative effect of insulin glargine by dose-response studies. Neither regular human insulin nor insulin glargine significantly altered $\left[{ }^{3} \mathrm{H}\right]$ thymidine incor- poration at physiological $(0.1-1 \mathrm{nmol} / 1)$ or supraphysiological concentrations (10-100 nmol/l) (Fig. 1b).

To confirm these findings, we independently assessed proliferation by analysis of Ki-67 expression, a nuclear marker of actively cycling cells. Basal and serum-stimulated Ki-67 expression was lower in HCASMCs than in HCAECs (Table 1). Neither regular human insulin, nor insulin glargine, at $10 \mathrm{nmol} / \mathrm{l}$ each, significantly altered Ki-67 expression (Table 1).

As a positive control for insulin effects in HCASMCs and HCAECs, phosphorylation of protein kinase B, a wellknown downstream target of insulin signalling [26], was investigated. As shown in Fig. 2, both regular human insulin and insulin glargine phosphorylated protein kinase B in a time-dependent manner.
Fig. 4 Lipoapoptosis of a HCAECs or $\mathbf{b}$ HCASMCs is not altered by co-incubation with regular insulin or insulin glargine. HCAECs and HCASMCs were co-incubated for $24 \mathrm{~h}$ with $1 \mathrm{mmol} / 1$ palmitate or stearate and $10 \mathrm{nmol} / \mathrm{l}$ regular insulin or insulin glargine. a For HCAECs, apoptosis was measured by determination of cells with sub-G1 DNA content as described in Materials and methods. Data are means \pm SE of three independent experiments $(n=3)$. Hatched bars, growth medium; black bars, regular insulin; grey bars, insulin glargine. b For HCASMCs, percentages of necrotic and apoptotic cells were determined by propidium iodide-annexin $\mathrm{V}$ double staining. Data are means \pm $\mathrm{SE}$ of four independent experiments. Solid shading, apoptosis; no shading, necrosis; grey shading, late apoptosis/necrosis $\mathbf{a}$

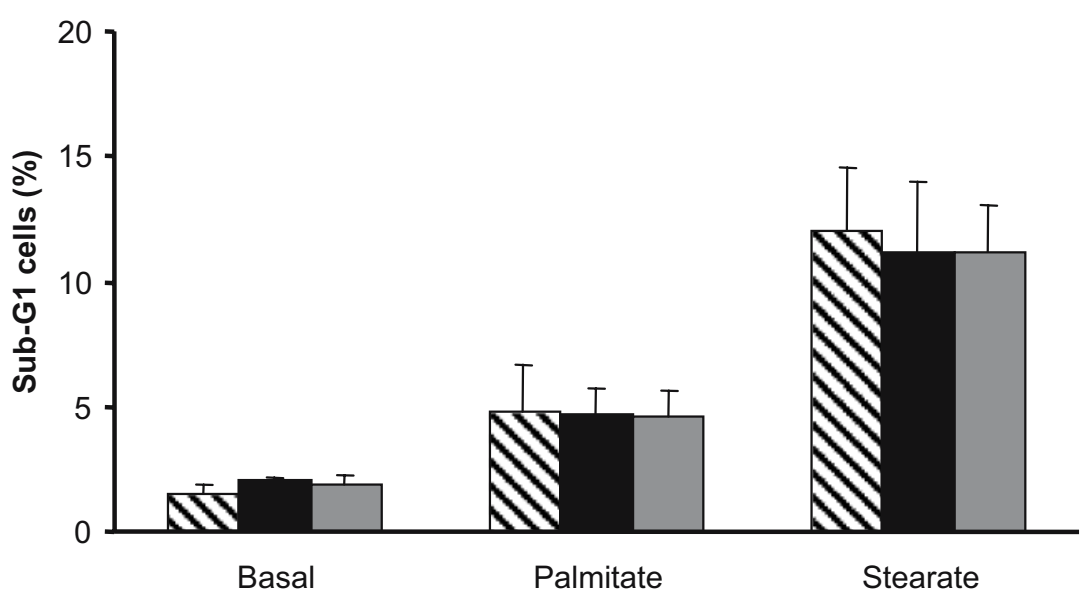

b

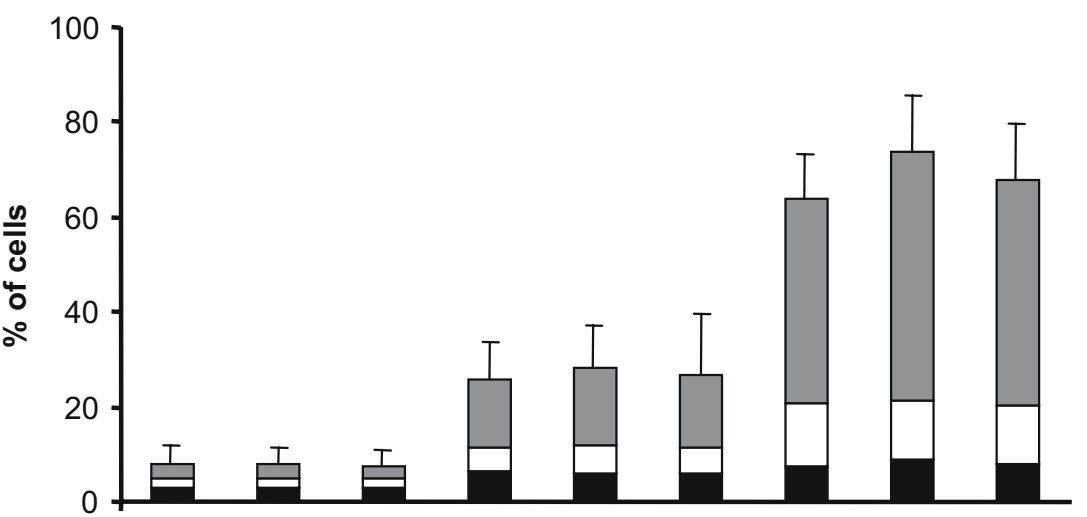

\begin{tabular}{|l|c|c|c|c|c|c|c|c|c|}
\hline Palmitate & - & - & - & + & + & + & - & - & - \\
\hline Stearate & - & - & - & - & - & - & + & + & + \\
\hline Regular insulin & - & + & - & - & + & - & - & + & - \\
\hline Insulin glargine & - & - & + & - & - & + & - & - & + \\
\hline
\end{tabular}


Fig. 5 Co-incubation of a HCAECs and b HCASMCs with regular insulin or insulin glargine does not prevent stearate-induced caspase activation. HCAECs and HCASMCs were co-incubated for $6 \mathrm{~h}$ with or without $1 \mathrm{mmol} / \mathrm{l}$ stearate and 10 or $100 \mathrm{nmol} / \mathrm{l}$ regular insulin or insulin glargine. DEVD-amccleaving activity was measured as described in Materials and methods. Data are means \pm SE of three independent experiments. Open bars, growth medium; shaded bars, stearate a

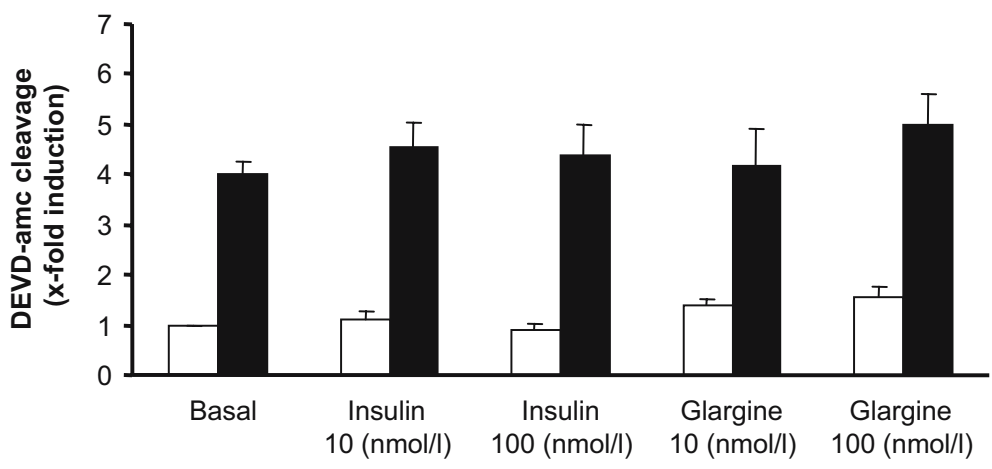

b

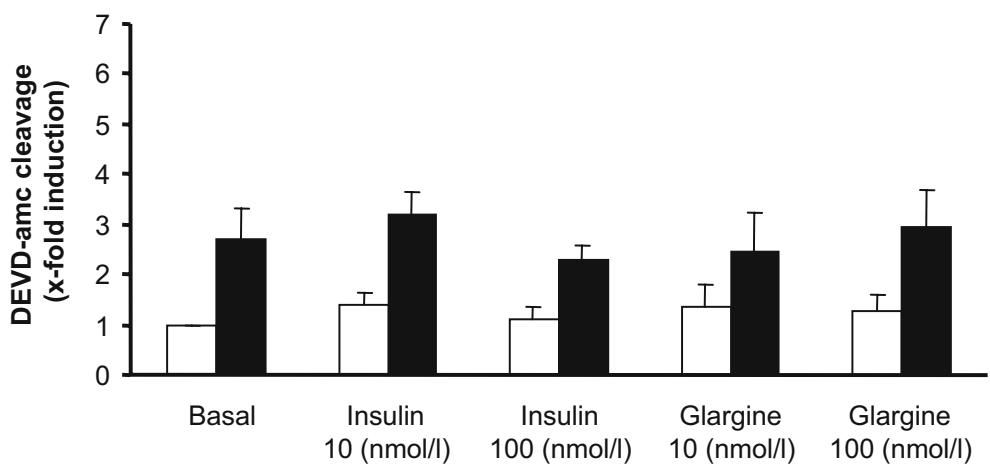

Since population growth is controlled by proliferation on the one hand and cell death on the other hand, we also determined apoptosis in insulin-treated cultures and untreated controls. HCAECs and HCASMCs were incubated for $24 \mathrm{~h}$ at physiological and supra-physiological concentrations of regular human insulin and insulin glargine ranging from 0.1 to $10 \mathrm{nmol} / 1$. Apoptotic HCAECs were determined by cell cycle analysis (quantification of subG1 DNA content). Neither regular human insulin nor insulin glargine significantly affected endothelial cell apoptosis (Fig. 3a).

In HCASMCs, propidium iodide-annexin $\mathrm{V}$ double staining was used to determine apoptotic and necrotic cell death. This method was chosen because HCASMCs were found to be essentially more sensitive to agent (e.g. NEFA)induced necrotic cell death than HCAECs. As shown in Fig. 3b, incubation of HCASMCs for $24 \mathrm{~h}$ with different concentrations of regular human insulin and insulin glargine (0.1-10 nmol/l) did not significantly alter cell viability.

To further examine whether insulin affects NEFA-induced cell death, we co-incubated HCAECs and HCASMCs with saturated NEFA (palmitate or stearate, $1 \mathrm{mmol} / \mathrm{l}$ ) and regular human insulin or insulin glargine for $24 \mathrm{~h}$. Palmitate and stearate significantly induced cell death in both cell types (Fig. 4a,b). Co-incubation with regular human insulin or insulin glargine, at $10 \mathrm{nmol} / 1 \mathrm{each}$, did not significantly alter NEFA-induced cell death $(4 a, b)$.

Furthermore, co-incubation with regular human insulin or insulin glargine had no significant influence on activa- tion of the pro-apoptotic caspase cascade as measured by DEVD-amc cleavage and shown for stearate in Fig. 5a,b.

\section{Discussion}

In the recent years, it has been recognised that proliferation as well as apoptosis of vascular cells plays a crucial role in the development and stability of atherosclerotic plaques [28]. Proliferation of vascular smooth muscle cells and intima-media thickening are key processes of early atherosclerosis [29], while apoptosis of endothelial or smooth muscle cells promotes coagulation by release of procoagulant microparticles $[30,31]$ and reduces cellularity of the atherosclerotic plaque, resulting in plaque instability and finally acute vessel occlusion [32].

Using low $(0.1 \mathrm{nmol} / \mathrm{l})$ and supraphysiological $(100 \mathrm{nmol} / \mathrm{l})$ concentrations of insulin, we mimicked the physiological as well as the extreme hyperinsulinaemic situation, the latter enabling cross-activity of insulin with the IGF-I receptor system. Despite being functionally active in HCAECs and HCASMCs as shown by phosphorylation of protein kinase $\mathrm{B}$, neither regular insulin nor insulin glargine increased DNA synthesis of HCASMCs or HCAECs. This is in accord with other studies showing little or no mitogenic effect of insulin on macrovascular cells $[16-20,22]$.

Human vascular smooth muscle cells as well as endothelial cells are reported to express both IGF-I receptors 
and insulin receptors [16, 23-25]. Studies in HUVECs have shown that these endothelial cells predominantly express IGF-I receptors $[24,25]$. Since insulin glargine reveals a somewhat higher (i.e. seven- to ten-fold) affinity for the IGF-I receptor than regular human insulin [7, 23], we also tested whether insulin glargine exerts mitogenic effects in HCAECs and HCASMCs. Insulin glargine, even at high concentrations, did not change the thymidine incorporation rate. This suggests that neither insulin nor insulin glargine is able to stimulate DNA synthesis in human coronary artery cells through signalling pathways dependent on insulin receptors or IGF-I-receptors.

Apoptosis of vascular cells is another central factor in the pathogenesis of atherosclerosis. Insulin was shown to prevent TNF- $\alpha$-induced apoptosis in HUVECs and to protect smooth muscle cells from apoptosis induced by serum starvation or oxidative stress [26, 33, 34]. Especially IGF-I receptor stimulation seems to be important for the viability of smooth muscle cells in human coronary arteries, as smooth muscle cells obtained from coronary atherosclerotic plaques show decreased expression of IGF-I receptors and increased sensitivity to apoptosis [35-37]. We showed here that in human coronary artery cells obtained from donors without coronary artery disease neither regular human insulin nor insulin glargine changes apoptosis and viability.

In insulin-resistant and type 2 diabetic patients, insulin levels as well as plasma concentrations of NEFA are often elevated. Recently, NEFA have been identified as a trigger of apoptosis in vascular endothelial cells [38]. We therefore imitated this pathological situation by co-incubation of HCAECs and HCASMCs with insulin and NEFA. In both cell types, palmitate as well as stearate significantly induced cell death. Regular human insulin or insulin glargine neither protected cells from NEFA-induced cell death nor enhanced NEFA-induced apoptosis or necrosis. Furthermore, no effect of regular insulin or insulin glargine on NEFA-induced activation of the caspase cascade was detectable.

In summary, our data demonstrate that insulin and insulin glargine do not influence cellularity in normal human coronary artery cells. Since the coronary artery cells tested were obtained from individuals without coronary artery disease and, as mentioned above, smooth muscle cells obtained from coronary atherosclerotic plaques reveal altered expression of IGF-I receptors, we cannot rule out the possibility that cells from patients with substantial cardiovascular disease may behave differently.

Acknowledgements We thank C. Haas for excellent technical assistance. This work was supported by DFG-KF0114, KennedyAllee 40, Bonn, Germany.

Duality of Interest

H.-U. Häring received consulting fees for participating on scientific boards of Aventis Pharma Deutschland, and has received grant support. M. Kellerer has received honoraria for speaking engagements from Aventis Pharma Deutschland, and was supported by a grant from Aventis Pharma. M.A. Schweitzer was employed by Aventis Pharma Germany until February 2005. He has still stock options in the company but no shares.

\section{References}

1. UK Prospective Diabetes Study Group (1998) Intensive bloodglucose control with sulphonylureas or insulin compared with conventional treatment and risk of complications in patients with type 2 diabetes (UKPDS 33). Lancet 352:837-853

2. Fritsche A, Schweitzer MA, Haring HU (2003) Glimepiride combined with morning insulin glargine, bedtime neutral protamine hagedorn insulin, or bedtime insulin glargine in patients with type 2 diabetes. A randomized, controlled trial. Ann Intern Med 138:952-959

3. Yki-Jarvinen H, Dressler A, Ziemen M, HOE 901/3002 study group (2000) Less nocturnal hypoglycemia and better postdinner glucose control with bedtime insulin glargine compared with bedtime NPH insulin during insulin combination therapy in type 2 diabetes. Diabetes Care 23:1130-1136

4. Riddle MC, Rosenstock J, Gerich J (2003) The treat-to-target trial: randomized addition of glargine or human NPH insulin to oral therapy of type 2 diabetic patients. Diabetes Care 26:3080 3086

5. Vehkavaara S, Makimattila S, Schlenzka A, Vakkilainen J, Westerbacka J, Yki-Jarvinen H (2000) Insulin therapy improves endothelial function in type 2 diabetes. Arterioscler Thromb Vasc Biol 20:545-550

6. Vehkavaara S, Yki-Jarvinen H (2004) 3.5 years of insulin therapy with insulin glargine improves in vivo endothelial function in type 2 diabetes. Arterioscler Thromb Vasc Biol 24:325-330

7. Kurtzhals P, Schaffer L, Sorensen A, Kristensen C, Jonassen I, Schmid C, Trub T (2000) Correlations of receptor binding and metabolic and mitogenic potencies of insulin analogs designed for clinical use. Diabetes 49:999-1005

8. Diabetologia (2004) Plasma insulin and cardiovascular mortality in non-diabetic European men and women: a meta-analysis of data from eleven prospective studies. Diabetologia 47:12451256

9. Caixas A, Ordonez-Llanos J, de Leiva A, Payes A, Homs R, Perez A (1997) Optimization of glycemic control by insulin therapy decreases the proportion of small dense LDL particles in diabetic patients. Diabetes 46:1207-1213

10. Taskinen MR, Kuusi T, Helve E, Nikkila EA, Yki-Jarvinen H (1988) Insulin therapy induces antiatherogenic changes of serum lipoproteins in noninsulin-dependent diabetes. Arteriosclerosis 8:168-177

11. Stentz FB, Umpierrez GE, Cuervo R, Kitabchi AE (2004) Proinflammatory cytokines, markers of cardiovascular risks, oxidative stress, and lipid peroxidation in patients with hyperglycemic crises. Diabetes 53:2079-2086

12. Dandona P, Aljada A, Mohanty P (2002) The anti-inflammatory and potential anti-atherogenic effect of insulin: a new paradigm. Diabetologia 45:924-930

13. Hansen TK, Thiel S, Wouters PJ, Christiansen JS, Van den Berghe G (2003) Intensive insulin therapy exerts antiinflammatory effects in critically ill patients and counteracts the adverse effect of low mannose-binding lectin levels. J Clin Endocrinol Metab 88:1082-1088

14. Banskota NK, Taub R, Zellner K, Olsen P, King GL (1989) Characterization of induction of protooncogene c-myc and cellular growth in human vascular smooth muscle cells by insulin and IGF-I. Diabetes 38:123-129

15. Pfeifle B, Ditschuneit HH, Ditschuneit H (1982) Binding and biological actions of insulin-like growth factors on human arterial smooth muscle cells. Horm Metab Res 14:409-414

16. Avena R, Mitchell ME, Carmody B, Arora S, Neville RF, Sidaway AN (1999) Insulin-like growth factor-1 receptors mediate infragenicular vascular smooth muscle cell proliferation in response to glucose and insulin not by insulin receptors. Am J Surg 178:156-161

17. Yamada H, Tsushima T, Murakami H, Uchigata Y, Iwamoto $Y$ (2002) Potentiation of mitogenic activity of platelet-derived growth factor by physiological concentrations of insulin via the MAP kinase cascade in rat A10 vascular smooth muscle cells. Int J Exp Diabetes Res 3:131-144 
18. Cruzado M, Risler N, Castro C, Ortiz A, Ruttler ME (1998) Proliferative effect of insulin on cultured smooth muscle cells from rat mesenteric resistance vessels. Am J Hypertens 11:5458

19. Kamide K, Hori MT, Zhu JH et al (2000) Insulin and insulinlike growth factor-I promotes angiotensinogen production and growth in vascular smooth muscle cells. J Hypertens 18:10511056

20. Agazie YM, Bagot JC, Trickey E, Halenda SP, Wilden PA (2001) Molecular mechanisms of ATP and insulin synergistic stimulation of coronary artery smooth muscle growth. Am J Physiol Heart Circ Physiol 280:H795-H801

21. King GL, Goodman AD, Buzney S, Moses A, Kahn CR (1985) Receptors and growth-promoting effects of insulin and insulinlike growth factors on cells from bovine retinal capillaries and aorta. J Clin Invest 75:1028-1036

22. King GL, Buzney SM, Kahn CR et al (1983) Differential responsiveness to insulin of endothelial and support cells from micro- and macrovessels. J Clin Invest 71:974-979

23. Chisalita SI, Arnqvist HJ (2004) Insulin-like growth factor I receptors are more abundant than insulin receptors in human micro- and macrovascular endothelial cells. Am J Physiol Endocrinol Metab 286:E896-E901

24. Nitert MD, Chisalita SI, Olsson K, Bornfeldt KE, Arnqvist HJ (2005) IGF-I/insulin hybrid receptors in human endothelial cells. Mol Cell Endocrinol 229:31-37

25. Zeng G, Quon MJ (1996) Insulin-stimulated production of nitric oxide is inhibited by wortmannin. Direct measurement in vascular endothelial cells. J Clin Invest 98:894-898

26. Hermann C, Assmus B, Urbich C, Zeiher AM, Dimmeler S (2000) Insulin-mediated stimulation of protein kinase Akt: a potent survival signaling cascade for endothelial cells. Arterioscler Thromb Vasc Biol 20:402-409

27. Eitel K, Staiger H, Rieger J et al (2003) Protein kinase C delta activation and translocation to the nucleus are required for fatty acid-induced apoptosis of insulin-secreting cells. Diabetes 52: 991-997
28. Geng YJ, Libby P (2002) Progression of atheroma: a struggle between death and procreation. Arterioscler Thromb Vasc Biol 22:1370-1380

29. Dzau VJ, Braun-Dullaeus RC, Sedding DG (2002) Vascular proliferation and atherosclerosis: new perspectives and therapeutic strategies. Nat Med 8:1249-1256

30. Bombeli T, Karsan A, Tait JF, Harlan JM (1997) Apoptotic vascular endothelial cells become procoagulant. Blood 89: 2429-2442

31. Mallat Z, Hugel B, Ohan J, Leseche G, Freyssinet JM, Tedgui A (1999) Shed membrane microparticles with procoagulant potential in human atherosclerotic plaques: a role for apoptosis in plaque thrombogenicity. Circulation 99:348-353

32. Libby P (1995) Molecular bases of the acute coronary syndromes. Circulation 91:2844-2850

33. Jamali R, Bao M, Arnqvist HJ (2003) IGF-I but not insulin inhibits apoptosis at a low concentration in vascular smooth muscle cells. J Endocrinol 179:267-274

34. Goetze S, Blaschke F, Stawowy P et al (2001) TNFalpha inhibits insulin's antiapoptotic signaling in vascular smooth muscle cells. Biochem Biophys Res Commun 287:662-670

35. Bennett MR, Evan GI, Schwartz SM (1995) Apoptosis of human vascular smooth muscle cells derived from normal vessels and coronary atherosclerotic plaques. J Clin Invest 95: 2266-2274

36. Patel VA, Zhang QJ, Siddle K et al (2001) Defect in insulin-like growth factor-1 survival mechanism in atherosclerotic plaquederived vascular smooth muscle cells is mediated by reduced surface binding and signaling. Circ Res 88:895-902

37. Okura Y, Brink M, Zahid AA, Anwar A, Delafontaine P (2001) Decreased expression of insulin-like growth factor-1 and apoptosis of vascular smooth muscle cells in human atherosclerotic plaque. J Mol Cell Cardiol 33:1777-1789

38. Artwohl M, Roden M, Waldhausl W, Freudenthaler A, Baumgartner-Parzer SM (2004) Free fatty acids trigger apoptosis and inhibit cell cycle progression in human vascular endothelial cells. FASEB J 18:146-148 